\title{
Editorial: The dissected city
}

Hugh Barton MPhil, Dip TP, MRTPI, FRSA, AcSS

Professor, University of West England, Bristol, UK

Looking across the contributions in this issue it is striking that many deal - in one way or another - with barriers. Some give reasons for the removal or avoidance of barriers, while others advocate them. In the first paper in this issue, Dobson (2012) is on the side of demolishing artificial barriers. The author examines historic landscape characterisation, arguing that landscape as a whole should be considered, rather than focus solely on a static list of special places. Chiaradia et al. (2012) examine (among other things) the difficulties of defining boundaries to town centres in London, stressing the significance of context. Finally, in the concluding paper of this issue Tomah (2012) reviews the design of housing in an Islamic community, concluding that building regulations should fully recognise the cultural need for privacy.

In contrast, the second briefing paper in this issue (Walshaw, 2012) reports the results of a housing improvement programme, finding that residents feel that the quality of a scheme relies on work in the wider environment, not just the home. Opening this issue Chris Webster, in a very thought-provoking briefing, contemplates a city of residential 'clubs': gated communities looking after their own needs (Webster, 2012). This idea is fascinating, and I want to examine it further.

Webster identifies a key factor in the rise of gated communities in some countries being the lack of faith in centralised bureaucracies delivering necessary services, while in a selfgoverning enclave you 'get what you pay for'. This principle of local control over your own environment echoes the views of police architectural advisors in the UK. They advocate cul-desac design, without connecting footpaths, so that there are no extra escape routes for criminals, no through-routes for rowdy teenagers. Residents often express the same views, valuing the sense of a 'home-patch', where neighbours are known, traffic is minimal and children can play. Yet of course the resulting layout is on the face of it diametrically opposed to the modern urban designers' creed. New urbanist and urban village principles lay great store on permeability: streets in grid or web patterns that allow easy pedestrian access in any direction, encouraging higher levels of pedestrian activity and social contact, with 'natural' surveillance keeping the streets safe.

Now, there may be ways to combine these apparently conflicting visions and get the best of both worlds, but I will leave that discussion for another time in order to concentrate on the core principle of locally-managed communities. Webster envisages (in a flight of fancy) the 'legal enclosure of neighbourhoods into residential, commercial and mixed use club communities' that take over the management of urban land, extending the genre established by shopping malls and gated residential developments (Webster, 2012: p.4). Only essential strategic infrastructure would still be planned centrally.

At one level this reminds me of anarchist thinking. William Morris, in the utopian tract 'news from nowhere' (Morris, 1890) imagines that the city withers away, like the state in Marxist theory, to be replaced by a decentralised patchwork of communes, wards or parishes, each managed by a regular gathering of neighbours working towards a degree of local self-sufficiency. The radical green movement of the 1970s and 1980s had much the same concept, promoting a decentralised pattern of ecosettlements - exemplified by the Centre for Alternative Technology in Wales, and Crystal Waters in Queensland. Webster's model (if I interpret it correctly) is more marketoriented, involving either management by a firm (as in a shopping mall) or co-operation between householders as part of a property owning democracy. Either way the image is seductive, returning power (and responsibility) to people to control their own environment, localising decisions about planning and design and reducing the heavy hand of state bureaucracy.

But a quick reality check gives pause for thought. There are three reasons why this utopian image is wrong. The first is due to the nature of capitalism. There is a 'natural' tendency for richer individuals and firms to shape the market in their own interests. An example of this is the pricing out of local people by secondhomers and retirees in much of Cornwall, UK. Other striking examples are the narrow autocracies (almost cabals) of housebuilders and food retailers in Britain. Even in the current dispensation these things are very apparent, only mitigated by centralised rules such as affordable housing obligations and (in a rather ineffectual way) retail planning guidance.

The second reason concerns physical form. Gated communities, shopping malls, business parks, hospital and university campuses all tend to exemplify the cul-de-sac mentality. They tend to create 'pods' of development, with limited access points and often no through-routes. These pods hang off the main road system, are almost invariably oriented around vehicle use, create barriers to non-motorised movement and restrict permeability. If development was dominated even more by 
the market (with co-operative housing groups acting as developers too) then the towns would become yet more segregated, socially polarised and car-dominated.

This leads on to the third reason. If we allow places to evolve into 'pod-land' - as has already happened to a significant extent in many outer city areas across the world - then we create an environment inimical to health. Active travel (walking and cycling to get somewhere) is the surest way to maintain healthy levels of physical activity, thus combating the evils associated with obesity. Car-oriented layouts deter active travel by traffic danger, increased distances and the separation of activities. Much recent research points to the significance of coherent planning for people on foot or bike for physical and mental wellbeing, social inclusion and carbon emissions. In-so-far as the vision of club-land implies pod-land, it is to be avoided.

However, the ideal of local community control remains. If we are to facilitate that without the associated downside of building unhealthy conditions into the very fabric of settlements, then the local authority has to play a strong role, while avoiding micro-management and allowing freedom to community groups. Difficult on both counts!

\section{REFERENCES}

Chiaradia A, Hillier B, Schwander C and Wedderburn M (2012)

Compositional and urban form effects on centres in Greater London. Proceedings of the Institution of Civil Engineers - Urban Design and Planning 165(1): 21-42, http://dx.doi.org/10.1680/udap.2012.165.1.21.

Dobson S (2012) Historic landscape characterisation in the urban domain. Proceedings of the Institution of Civil Engineers - Urban Design and Planning 165(1): 11-19, http://dx.doi.org/10.1680/udap.2012.165.1.11.

Morris W (1890) News from nowhere. Commonweal, January $11^{\text {th }}$.

Tomah AN (2012) Visual privacy in residential areas: amendment of building regulations. Proceedings of the Institution of Civil Engineers - Urban Design and Planning 165(1): 43-53, http:// dx.doi.org/10.1680/udap.2012.165.1.43.

Walshaw A (2012) Briefing: Understanding housing modernisation from the bottom up. Proceedings of the Institution of Civil Engineers - Urban Design and Planning 165(1): 7-10, http://dx.doi.org/10.1680/udap.2012.165.1.7.

Webster C (2012) Briefing: Cities of clubs. Proceedings of the Institution of Civil Engineers - Urban Design and Planning 165(1): 3-6, http://dx.doi.org/10.1680/udap.2012.165.1.3. 